\title{
Public Disclosure of Internal Revenue Service Private Letter Rulings
}

Private letter rulings are used by the Internal Revenue Service to inform taxpayers of the tax consequences of prospective transactions or events. ${ }^{1}$ The contents of these letter rulings are generally not disclosed to the public, ${ }^{2}$ a practice that has evoked criticism from scholars, legislators, and private practitioners. ${ }^{3}$ These critics contend that nondisclosure of letter rulings reduces public confidence in the Service, gives an inequitable advantage to some taxpayers, obstructs useful input from outside the Service, and violates the Freedom of Information Act. Opponents of disclosure cite the problems inherent in permitting all taxpayers to utilize a ruling tailored to a single taxpayer's situation, and the problems involved in maintaining the confidentiality of letter recipients' identities and transactions. ${ }^{4}$ This comment discusses the present disclosure rules of the letter ruling program, their validity under the Freedom of Information Act, and suggests that full disclosure of letter rulings is required by law, not difficult to institute in practice, and a desirable policy.

\section{The Present Ruling Process}

Private letter rulings are issued by the National Office of the Internal Revenue Service in response to requests for a determination of the tax consequences of contemplated events or transactions. ${ }^{5}$ The Internal Revenue Code explicitly makes such rulings a prerequisite to certain types of transactions. ${ }^{6}$ Even where a letter ruling is not required by law,

1 Rev. Proc. 72-3, 1972 Int. Rev. BuLc. No. 1; 26 C.F.R. § 601.201(a)(2) (1972).

226 G.F.R. \& 601.702(b)(1) (1972).

3 See 111 Cong. REc. 11810 (1965) (remarks of Senator Gore); Report to tHE House

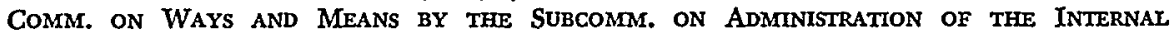
Revenue Laws (Subcomm. Print 1952, 1953) [hereinafter cited as SUbcomm. REPORT]; Davis, The Information Act: A Preliminary Analysis, 34 U. CHr. L. REv. 761, 773 (1967); Reid, Public Access to Internal Revenue Service Rulings, 41 GEO. WASH. L. REv. 23 (1972).

4 See Caplin, Taxpayer Rulings Policy of the Internal Revenue Service: A Statement of Principles, N.Y.U. 20TH INsT. ON FED. TAX 1, 26-29 (1962); Dwan, The Federal Administrative Procedure Act and the Bureau of Internal Revenue, in THE FEDERAI ADministrative Procedure Act aNd the Administrative Agencies I63 (G. Warren ed. 1947). For a general discussion of other objections, see Rogovin, The Four R's: Regulations, Rulings, Reliance and Retroactivity, $A$ View From Within, 43 TAxEs 756, 757 n.60 (1965).

5 Sources cited note 1 supra.

6 INT. REv. CODE of 1954, $\S \S 367,446(\mathrm{c}), 706(\mathrm{~b})(1)$; see Sugarman, Federal Tax Rulings Procedure, 10 TAX L. REv. 1, 5-6 (1954). 
it is frequently a practical necessity. ${ }^{7}$ For example, a leading authority on corporate taxation has noted that "almost all reorganization exchanges involving the shareholders of publicly held corporations . . . are conditioned on a favorable ruling by the Internal Revenue Service. ..."8

Letter rulings are desirable because of the tax certainty they provide the recipient. The information supplied by the Service generally satisfies the taxpayer's need to anticipate the tax consquences of his transaction. ${ }^{9}$ In addition, where certain conditions are met $^{10}$ the treatment proposed in the ruling is in a practical sense "binding" on the Service for that transaction. ${ }^{11}$

The concept of "binding effect" is an elusive one. In the absence of an abuse of discretion, ${ }^{12}$ the Commissioner technically has the authority to revoke letter rulings retroactively, as well as prospectively, in order to "correct mistakes of law in the application of the tax laws to particular transactions"13 _even where the taxpayer may have relied to his det-

7 A number of commentators have noted that many practitioners consider private letter rulings a form of insurance against surprises, even when the practitioner knows that no successful challenge to the transaction can be made. See Rose, The Rulings Program of the Internal Revenue Service, 35 TAxes 907, 910 (1957). Another commentator has noted that "[i]t is always prudent if possible to obtain a private ruling where substantial sums are involved." Taylor, Tax Rulings: New Rules and Procedures, N.Y.U. 21sT INST. ON FED. TAX. 69, 91 (1963).

8 B. Bittker \& J. Eustice, Federal Taxation of Corporations and Shareholders f 14.07 (3rd ed. 1971); see Malzeke, Gurrent I.R.S. procedure for issuing rulings in reorganization cases: how it operates, $27 \mathrm{~J}$. TAx. 336 (1967).

9 See Sugarman, supra note 6, at 4. Even an "adverse ruling"-one stating the Service's intention to treat the transaction differently than the recipient desired-may help a taxpayer to reformulate his transaction so as to avoid a costly conflict with the Service. Id. at 4, 39; Yager, When and how should the practitioner ask for rulings and technical advice?, 14 J. TAx. 38 (1961).

10 See text at note 17 infra.

11 "A ruling issued to a taxpayer with respect to a particular transaction represents a holding of the Service on that transaction only. However, the application of that ruling to the transaction will not be affected by the subsequent issuance of regulations (either temporary or final), if the conditions specified in section $13.05 \ldots$ are met." Rev. Proc. 72-3 \& 13.06, 1972 INT. REv. BuLL. No. 1. For the conditions specified in $\S 13.05$, see text at note 17 infra.

12 In Lesavoy Foundation v. Commissioner, 238 F.2d 589 (3rd Gir. 1956), a charitable foundation was granted a ruling exempting it from taxation. After the foundation had operated for a number of years under the ruling, the Commissioner revoked the ruling retroactively and required payment of back taxes. The court held that this action was an abuse of discretion. Although the Commissioner "may change his mind when he believes he has made a mistake in a matter of fact or law ... [i]t is quite a different matter to say that having once changed his mind, [he] may arbitrarily and without limit have the effect of that change go back over previous years during which the taxpayer operated under the previous ruling." $I d$. at 591 .

13 Dixon v. United States, 381 U.S. 68, 72 (1964). See also Rev. Proc. 72-3 § 13.04, 1972 Int. Rev. Bull. No. 1. In Auto Club v. Commissioner, 353 U.S. 180 (1957), the 
riment on the erroneous ruling. ${ }^{14}$ In practice this authority is rarely exercised, largely because the Service recognizes that many transactions could not be concluded without a high degree of certainty as to tax consequences, and that inequity results from application of new or revised regulations and rulings to taxpayers who have relied on a previous Service position..$^{15}$

In furtherance of the policy enunciated by Congress in section 7805 (b) of the Internal Revenue Code, ${ }^{16}$ under which the Commissioner may apply any new or changed position without retroactive effect, the Service's position is that "except in rare or unusual circumstances," a letter ruling will not be retroactively revoked or modified with respect to the taxpayer for whom the ruling was originally issued if:

(1) there has been no misstatement or omission of material facts, (2) the facts subsequently developed are not materially different from the facts on which the ruling was based, (3) there has been no change in the applicable law, (4) the ruling was originally issued with respect to a prospective or proposed transaction, and (5) the taxpayer directly involved in the ruling acted in good faith in reliance upon the ruling and the retroactive revocation would be to his detriment. ${ }^{17}$

The change in the policy guideline from the 1954 statement that revocation would be "generally" prospective ${ }^{18}$ to the present policy of no retroactive revocation except in rare or unusual circumstances ${ }^{19}$ has

Court limited the reach of Lesavoy. The auto club had received rulings in 1934 and 1938 granting tax-exempt status. In 1945, the Commissioner revoked this status, applying the revocation retroactively to 1943-1944. Although the club claimed that the Commissioner's action was barred by Lesavoy, the Court held that the Commissioner was not barred from correcting a mistake of law. Lesavoy was distinguished as a case where the Commissioner had abused his discretion. The Court noted that in the Auto Glub case, the Commissioner had dealt with the plaintiff auto club on the same basis as other auto clubs and held that, as a consequence, the revocation was not an abuse of discretion.

14 See Manhattan General Equip. Co. v. Commissioner, 297 U.S. 129 (1946). In Dixon v. United States, 381 U.S. 68 (1965), the Court noted that retroactive revocation is " $a$ reflection of the fact that Congress, not the Commissioner, prescribes the tax laws. The Commissioner's rulings have only such force as Congress chooses to give them, and Congress has not given them the force of law. Consequently ... the Commissioner's acquiescence in an erroneous decision, published as a ruling, cannot in and of itself bar the United States from collecting a tax otherwise lawfully due." Id. at 73.

15 See Rogovin, supra note 4, at 762-63 n.32.

16 "The Secretary or his delegate may prescribe the extent, if any, to which any ruling or regulation, relating to the internal revenue laws, shall be applied without retroactive effect." INT. REv. CODE OF 1954, § 7805(b).

17 Rev. Proc. 72-3 § 13.05, 1972 INT. REv. BuLL. No. 1; 26 G.F.R. § 601.201(L)(5) (1972).

18 Rev. Rul. 54-172, 1954-1 CuM. BuLL. 394, 401.

19 See text at notes 16-17 supra. 
been said to reflect the intent of the Service "to permit and encourage [the requesting taxpayer's] reliance on letter rulings."20

Thus, although the Commissioner is not required to limit revocation to prospective application, if the conditions in the guidelines are satisfied there is little chance that revocation will be retroactive, ${ }^{21}$ even where the original ruling was erroneous. ${ }^{22}$ An indication of the safety and certainty of rulings is the fact that in 1964, approximately 40,000 ruling requests were made but only four requests for statutorily binding closing agreements were submitted. ${ }^{23}$ Practitioners apparently see little effective difference in binding effect beween closing agreements and letter rulings.

The taxpayer is not the only beneficiary of the letter rulings program. Representatives of the Service claim that it provides them with several advantages: the promotion of an efficient and economical system of voluntary compliance, ${ }^{24}$ a greater uniformity in the application of the law through centralized interpretation, ${ }^{25}$ the enunciation of principles for use by tax officials as well as taxpayers and practitioners, ${ }^{28}$ the provision of information to the Service, in advance of audit, as to the types of problems that are likely to arise, ${ }^{27}$ and a decrease in the amount of litigation that would otherwise result. ${ }^{28}$

Letter ruling recipients and the Service appear quite satisfied with the manner in which this system provides tax certainty. Critics have noted, however, that the Service does not generally make public the contents of private letter rulings, regardless of their usefulness to other taxpayers. ${ }^{29}$ Only Revenue Rulings, ${ }^{30}$ official interpretations by the Ser-

20 Rogovin, supra note 4, at 769.

21 "[T]n discussing this with our rulings people, they were unable to recall any instance [of retroactive revocation] where the conditions were satisfied." Caplin, supra note 4, at 21.

22 See Rev. Proc. 72-3 §§ 13.04, 13.05, 1972 INT. Rev. Bull. No. 1; 26 G.F.R. $\& 601.201(L)(4),(5)(1972)$.

23 A closing agreement is usually based on a ruling but it is statutorily binding on the Service. INT. REv. CoDE of 1954, \& 7121; 26 C.F.R. \& 601.201(a)(6) (1972). "[]]t may be entered into where it is advantageous to have the matter permanently and conclusively closed ...." Id. The 1964 figures are cited in Rogovin, supra note 4, at 770.

24 Caplin, supra note 4, at 7; Sugarman, supra note 6, at 5 .

25 Caplin, supra note 4, at 7; Rogovin, supra note 4, at 765; Sugarman, supra note 6, at 9.

26 Caplin, supra note 4, at 7; Sugarman, supra note 6, at 12.

27 Caplin, supra note 4, at 7; Rogovin, supra note 4, at 765; Sugarman, supra note 6, at 5 .

28 Rogovin, supra note 4 , at 765 .

29 See text and notes at notes 1-8 supra.

30 "A 'Revenue Ruling' is an official interpretation by the Service that has been published in the Internal Revenue Bulletin. . . Taxpayers generally may rely upon Revenue 
vice published in the Internal Revenue Bulletin, are available to the public. The Service maintains that it selects for publication as Revenue Rulings all letter rulings having "substantial value as precedents," 31 yet in 1971, only 633 such Rulings were published as compared to the issuance of 32,297 private letter rulings. ${ }^{32}$ The experience of many practitioners has shown that a large number of unpublished private letter rulings are significant indicators of policy. ${ }^{33}$

\section{The Full Disclosure Proposal}

All letter rulings should be made accessible to the public at Internal Revenue Service Reading Rooms. ${ }^{34}$ Full disclosure would prevent favoritism, thereby preserving public confidence in the Service; it would guarantee equality of access to the Service's positions on tax problems; and it would increase the value of policy inputs from outside the Service. Perhaps most important, full disclosure would bring the Service's rulings policy into compliance with the Freedom of Information Act.

\section{A. Public Confidence and Suspicion of Favoritism}

The Service's effectiveness depends heavily on public faith in the evenhanded administration of the tax laws. ${ }^{35}$ In recent years, fears of

Rulings published in the Bulletin in determining the tax treatment of their own transactions and need not request specific rulings applying the principles of a published Revenue Ruling to the facts of their particular cases." Rev. Proc. 72-1, 1972 INT. Rev. BuLc. No. 1. Revenue Rulings are primarily derived from three sources: letter rulings, significant court decisions, and requests for technical advice.

31 Rogovin, supra note 4, at 765 . The Service normally does not publish a Revenue Ruling in an area unless a need for guidance is indicated by the public, IRS field offices, or the courts. $I d$. at $765-66$. The relative value of some rulings, as precedent or guidance, does not compel the conclusion that no others should be made public. Other considerations, such as eliminating secrecy, weigh heavily in favor of full disclosure.

321971 Internal Revenue Service ANNUAL Report 7-8.

33 Javaras, Krane, \& Levin, Public Hearings for Private Rulings: A Dissent, in Compendium: The Public and the Ruling Process 72-131, 72-136 (1972) [hereinafter cited as Compendum].

34 The Service maintains a number of Reading Rooms in major population centers across the country where Service publications are available. Former Chief Counsel Rogovin also briefly suggested that letter rulings be made available in this fashion. See Reid, supra note 3 , at 34 .

35 "The most powerful factor of all in undermining confidence in the decision making process in Washington is the secrecy that surrounds so much of it." Zalaznick, The Small World of Big Washington Lawyers, ForTune, Sept. 1969, at 121, cited in Reid, supra note 3, at 27. See Cooper, Comments, in CoMpendium, stupra note 33, at 72-123: "It is essential to our system of self-enforcement that the public have confidence in the fairness of income tax administration and decision. If a matter of this magnitude is decided in a back room, without any airing of views from any except self-interested parties, public confidence will be adversely affected." 
secret favoritism by the Service in the issuance of private letter rulings have prompted demands for disclosure of private letter rulings. ${ }^{36}$ In 1965 , Senator Gore described to the Senate a loss of $\$ 56$ million in revenue that resulted from a last minute change in a Treasury ruling "negotiated and issued in secrecy, and contrary to the clear intent of the Congress." 37 Gore viewed the ruling change as "an unfortunate instance of secret tax favoritism." 38 To combat the problem, he introduced a bill requiring the publication of Treasury rulings where revenues would be affected by $\$ 100,000$ or more in any fiscal year. ${ }^{39}$

Full disclosure of letter rulings would assure that neither incompetence that gives a competitive advantage by erroneously ruling in the recipient's favor, nor deliberate favoritism is being concealed, and would promote indispensable confidence in the rulings process and the tax system in general..$^{40}$

\section{B. Equality of Access}

Although private letter rulings are not generally available to the public, such rulings are available to some tax practitioners, particularly those in large tax firms. ${ }^{41} \mathrm{~A}$ few letter rulings become widely available through publication in tax periodicals ${ }^{42}$ and reporting services to which practitioners make available rulings they consider useful. ${ }^{43} \mathrm{In}$ dependent firm files and letter ruling exchange groups within the tax bar provide a more selective distribution of a wide variety of "private"

36 See SUbComa. Report, supra note 3, at 30: "[The] availability [of IRS decisions] to public scrutiny should serve as a deterrent to favoritism and enable the public to satisfy itself as to the impartiality of tax administration."

37111 CoNG. REc. 11810 (1965).

38 Id.

39 Id. The bill was not enacted into law. For other examples of "problem cases" where large sums of revenue were "lost," see CoMPENDrum, supra note 33, at 72-104. A bill that would make known to Congress any proposed ruling having a great effect on revenues was proposed in 1971 by Representative Ullman. H.R. 9513, 92d Cong., Ist Sess. (1971).

40 See letter from Senator William Proxmire to Secretary of the Treasury John Connally, Sept. 25, 1971, cited in CoMpendium, supra note 33, at 72-111: "Although I have no doubt as to the integrity of the experts in the Internal Revenue Service who draft these revenue rules, bringing the process out into the open will alleviate the doubts expressed by others regarding the propriety of the contacts with those seeking more revenue rulings." Wall Street Journal, June 13, 1973, p. 1, col. 5, reported the hope of Tax Analysts and Advocates, a public interest tax law firm, that "[t]he end of secrecy should mean fairer tax rulings with less hanky-panky."

41 Reid, supra note 3, at 28 n.30.

42 See, e.g., Shop Talk, J. TAX.; Points to Remember section of the ABA TAX LAwYER. See also Reid, supra note 3 , at 29 n.32.

43 Reliance on a Commerce Clearing House published letter ruling was the basis for the dispute in Bookwalter v. Brecklein, 357 F.2d 78 (8th Cir. 1966). 
letter rulings. ${ }^{44}$ The readers of these distributions apparently consider the positions and trends discernible in these rulings important, in spite of the fact that the rulings have no value as binding precedents. ${ }^{45}$ For example, where speed is important, a tax adviser may approve a transaction largely on the basis of his assessment of the Service's position as evidenced by privately distributed letter rulings. ${ }^{46}$ It has also been noted that reference to an analogous letter ruling can be helpful in negotiating with the Service for a desired ruling ${ }^{47}$ and that there is evidence that the Service itself refers to private rulings in determining the treatment appropriate for a similar case..$^{48}$

As a result of the Service's stance against full disclosure, those who privately obtain a large sample of letters may receive a competitive advantage. A general availability program, in many ways merely a legitimization and expansion of the practice that already exists in a number of large law firms, would eliminate this disparity. All taxpayers and tax advisers would be able to examine the Service's treatment of pertinent transactions ${ }^{49}$ and to use the information gained as a basis either for requesting a similar ruling or for proceeding with the transaction in the hope that the position of the Service will not change. ${ }^{50}$

44 See Reid, supra note 3, at 28 n.31; Tax Analysts v. IRS, Civil No. 841-72 (D.D.G. June 6, 1973), at 14; interviews by the author with members of the New York and Chicago tax bar.

45 Rev. Proc. 72-3 \& 13.01, 1972 INr. REv. BuLc. No. 1.

46 Interviews by the author with members of the tax bar in New York and Chicago.

47 Reid, supra note 3, at 33. Through a written explanation to the Service accompanying his request and a conference with Service personnel, a taxpayer may even participate in shaping the ruling. 26 C.F.R. $\$ 601.201(\mathrm{e})(4)$, (9), (f)(1)(2) (1972). In this manner, a taxpayer may actually negotiate with the Service for the type of treatment he wishes his transaction to receive. An IRS deposition in Tax Analysts indicates that "if a previously issued private letter ruling or a similar situation is called to the attention of the IRS in formulating a newly requested ruling the prior ruling will be regarded as most persuasive, if not dispositive." Tax Analysts v. IRS, Civil No. 841-72 (D.D.C. June 6, 1973), at 9, notice of appeal filed, D.C. Cir., Aug. 3, 1973.

48 Reid, supra note 3, at 33. A more recent reference to this practice may be found in Tax Analysts v. IRS, Civil No. 841-72 (D.D.C. June 6, 1973), where the Service admitted in its deposition that letter rulings deemed to have "a continuing 'reference' value for internal IRS purposes" are placed in a permanent reference file along with court decisions, published Revenue Rulings, and other materials deemed to have a continuing reference value. $I d$. at 3,8 .

49 This was one of the goals sought to be achieved by the publication of SEC no-action letters. See 1 ReCOMMENDATIONS AND REPORTS OF THE ADMINISTRATIVE CONFERENCE OF the UNITED STATES 437 (1968-1970). After some prodding by the Administrative Conference, an "availability" plan was adopted with provisions similar to the ones to be proposed here. Id., see SEC Act Release No. 8931 (1970); 17 C.F.R. § 200.81 (1972).

50 Interviews by the author with members of the tax bar in New York and Chicago. 


\section{The Increased Value of Inputs From Outside the Service}

Sound decision making generally calls for a broad representation of views ${ }^{51}$ in order to elicit "the information, facts, and probabilities which are necessary to fair and intelligent action."52 Public disclosure of letter rulings would allow broader public input through comments on rulings issued and requests for similar rulings. Such input is presently available only when letter rulings are published as Revenue Rulings. The present "closed" decision making process may, in some circumstances, lead to the mistaken elimination of an entire class of transactions, through the momentum of past decisions. ${ }^{53}$ Questioning of letter rulings-whether by other practitioners pressing for a different result, "public watchdogs," members of Congress, or legal scholars-would tend to prevent the perpetuation of mistakes that may creep into the system because of the limited review now available for letter rulings ${ }^{54}$ and the limited input received from outside the Service. Such comments would also force the reexamination of a larger number of important and frequently requested rulings, and would discourage perfunctory issuance of a ruling similar to previous ones. This reexamination process would provide an expanding body of sound precedent in the form of published Revenue Rulings and letter rulings.

\section{The Freedom of Information Act}

The policy considerations outlined above can be seen as part of the general concern over administrative secrecy that motivated the passage of the Freedom of Information Act. ${ }^{55}$ President Johnson, on signing the Freedom of Information Act, noted that "a democracy works best when the people have all the information that the security of the Nation permits. No one should be able to pull the curtains of secrecy around

51 See Robinson, The Making of Administrative Policy: Another Look at Rulemaking and Adjudication and Administrative Procedure Reform, 118 U. PA. L. REv. 485, 515 (1970).

62 Final Report of the Attorney General's Committee on Administrative Procedure 102 (1941). See also Crampton, The Why, Where \& How of Broadened Public Participation in the Administrative Process, 60 GEO. L. J. 525, 528 (1972); Popkin, A Critique of the Rule-making Process in Federal Income Tax Law With Special Reference to Conglomerate Acquisitions, 45 IND. L.J. 453, 504 (1970): "The whole point [of permitting public comment via publication of letter rulings] would be to encourage critical scrutiny by the public of private rulings to see if there was error."

58 Cf. Note, The Availability and Reviewability of Rulings of the Internal Revenue Service, 113 U. PA. L. REv. 81, 94 (1964).

54 See notes 98-99 infra; Davis, supra note 3, at 773; Popkin, supra note 52, at 495-96. ธ6 81 Stat. 54 (1967), amending 80 Stat. 250 (1966), (codified at 5 U.S.C. $\S 552$ (1972)). 
decisions which can be revealed without injury to the public interest." 56 It is clear that private letter rulings should be included in the category of information that must be disclosed to the public. The intent of the Act was to open to public inspection all government information not required to be kept secret for reasons of national security or the protection of privacy. ${ }^{57}$ Section 3(a) of the Act requires requires publication in the Federal Register of "substantive rules of general applicability ... and statements of general policy or interpretations of general applicability . . , ,58 and Section $3(\mathrm{~b})$ requires that statements of policy and interpretations that have been adopted by the agency and are not published in the Federal Register must be indexed and made available for public inspection and copying. ${ }^{59}$

It is fairly clear that under the 1946 Administrative Procedure Act's Information Section ${ }^{60}$ interpretations such as private letter rulings were not covered by the publication or availability requirements ${ }^{61}$ unless they were adopted "for the guidance of the public;"62 the language of the new statute, however, is much broader and should be read as covering private letter rulings. ${ }^{63}$ Private letter rulings are interpretations of the

56 Attorney General's Memorandum on the PUblic Information Section of the Adannistrative Procedure Act ii (1967) [hereinafter cited as 1967 Att'y Gen. Memo.]

57 " $[F]$ reedom of information is so vital that only the national security, not the desire of public officials or private citizens, should determine when it must be restricted." Information should be made available "to the full extent consistent with individual privacy and with the national interest." Id. (Statement of President Johnson).

585 U.S.C. $\$ 552(\mathrm{a})(\mathrm{l})(\mathrm{D})(1970)$.

595 U.S.C. $\$ 552(\mathrm{a})(2)(1970)$.

60 Act of June 11, 1946, ch. 324, § 4, 60 Stat. 238.

61 See Administrative Procedure Act Legislative History, 79th Cong., 2d Sess. 355 (1946) (comments of Congressman Walter) [hereinafter cited as LegrsLative HistoRY]; ATtorneY General's Manual on the Administrative Procedure Act 22-23 (1947); Attorney General's Memorandum to the Heads of Departments and Agencies on the administrative Procedure Act 8 (1946): "For example, a reply from the agency's general counsel to an inquiry from a member of the public as to the applicability of a statute to a specific set of facts need not be published."

"The [Internal Revenue] Bureau has held that opinions of a Deputy Commissioner addressed to a particular taxpayer or upon a particular set of facts, all opinions of the Chief Counsel for the Bureau, all rulings of internal revenue agents, and the like, are not subject to the provisions of sec. 3(a)(3) or sec. 3(b) and need not be published in the Federal Register, Internal Rev. Bulletin, or elsewhere." Dwan, supra note 4, at 147-48.

62 See Legislative History, supra note 61, at 199.

03 The old $\S 3(\mathrm{a})$ covers substantially the same material covered under the new $\S 3(\mathrm{a})$ :

Old $\$ 3(a)$

Every agency shall separately state and currently publish in the Federal Register. (3) substantive rules adopted as authorized by law and statements of general policy or interpretations formulated and adopted by the agency for the guidance of the public, but not rules addressed to and served upon named persons in accordance with law.
New \& 3(a)

Every agency shall separately state and currently publish in the Federal Register for the guidance of the public ... (D) substantive rules of general applicability adopted as authorized by law, and statements of general policy or interpretations of general applicability formulated and adopted by the agency .... 
revenue laws ${ }^{64}$ and are "adopted" within the meaning of the statute. ${ }^{65}$ They thus appear to fall within the availability requirements of Section $3(\mathrm{~b})$. As noted above, however, the Service has refused to disclose their contents to the public.

Following the lead of many other administrative agencies, ${ }^{66}$ the Service maintains that under the availability section of the 1966 Act, only matters of precedential significance must be made available to the public. ${ }^{87}$ The Service concludes that under this interpretation, private letter rulings need not be made public. ${ }^{68}$

The authority for this interpretation is found in the Attorney General's Memorandum on the Freedom of Information Act, ${ }^{69}$ a pamphlet designed to help Federal agencies comply with the Act. The Attorney General, relying on the House Committee Report ${ }^{70}$ on the Act, stated that the availability section "covers statements and interpretations which are not of general applicability, but which the agency may rely on as precedents."71 Under this interpretation of the availability section, "an agency may not be required to make available for public inspection and copying any advisory interpretation on a specific set of facts which is requested by and addressed to a particular person," provided the interpretation is not relied on as precedent. ${ }^{72}$

The new Section 3(b), however, is far broader than the comparable provision of the 1946 Act:

Old § 3(b)

Every agency shall publish or, in accordance with published rule, make available to public inspection all final opinions or orders in the adjudication of cases (except those required for good cause to be held confidential and not cited as precedents) and all rules.

64 See Davis, supra note 3, at 772-73; Levin, The Reliability of Published Tax Materials, 40 N.Y.S.B.J. 269, 274 (1968); Rogovin, supra note 4, at 766; Sugarman, supra note 6, at 2; Letter from Samuel R. Pierce, Jr., General Counsel of the Treasury Department to Senator William Proxmire, Oct. 20, 1971, cited in CoMpendiuM, supra note 33, at 72-115, 72-117: "Such rulings and advice do not represent policy decisions but interpretations of the Internal Revenue Code."

651967 ATT'Y GEN. MEMo., supra note 56, at 16.

B6 FCC, 47 C.F.R. $\S$ 0.445(d) (1972); NASA, 14 C.F.R. $\S 1206.200(\mathrm{~b})$ (ii) (1972); Treasury, 31 C.F.R. § 1.3(c) (1972); Renegotiation Board, 32 C.F.R. $\S 1480.5$ (a) (1972). But see Federal Maritime Comm'n, 46 C.F.R. $\$ 503.21$ (1972); SEC, 17 C.F.R. $\$ 200.81$ (1972).

67 26 C.F.R. § 601.702(b) (1972).

68 Id. "Nor does [the availability section of the Freedom of Information Act] apply to any ruling or advisory interpretation which is issued to a taxpayer on a particular transaction or set of facts and applied only to that transaction or set of facts." See Tax Analysts v. IRS, Civil No. 841-72 (D.D.C. June 6, 1973), at 4.

691967 ATr'Y GEN. MEMo, supra note 56.

70 H.R. REP. No. 1497, 89th Cong., 2d Sess. (1966).

711967 ATT'Y GEN. MEMo., supra note 56, at 16 (emphasis added).

72 Id. (citing H.R. REP. No. 1497, 89th Cong., 2d Sess. (1966), at 7). 
If the House Committee's interpretation is correct, private letter rulings are excluded from the availability section of the Act; only rulings of precedential significance, namely Revenue Rulings published in the Internal Revenue Bulletin, must be made available. The House Report, however, is in conflict with the language of the statute, the history of the Act in the Senate, and judicial interpretation of the Act.

1. The Text of the Statute. Nowhere does the language of the Act impose the limitations suggested by the House Report; the availability section does not in any way restrict disclosure to matters of precedential significance. The Act does provide that matter not properly published, made available, or indexed may not be used as precedent, and the Attorney General's Memorandum seems to imply that the limitations imposed by this sanction should define the agency's duty of compliance. ${ }^{73}$ As Professor Davis notes, however, it is doubtful that Congress intended to allow agencies to violate the Act so long as they could tolerate the sanction. ${ }^{74}$ Even if the reach of the Act's sanctions is used to define the duty of compliance, "precedential significance" is not the point at which disclosure may stop. A broader sanction is available under the Act: if an agency refuses to disclose information required to be made available under any of the sections of the Act, any person may seek an injunction compelling disclosure. ${ }^{75}$ Thus, even under the sanctions test the agency's duty is to disclose "information required to be made available,"76 not merely that with precedential significance.

2. The Legislative History. The Senate Committee Report does not mention the limitations on disclosure under the availability section noted in the House Report; instead it emphasizes the Act's declaration that no information may be withheld "unless explicitly allowed to be kept secret by one of the exemptions in subsection (e)" of the Act, ${ }^{77}$ thus contradicting the implication in the House Report that there may in fact be other limitations on disclosure. ${ }^{78}$

Prior to the passage of the Freedom of Information Act, Internal Revenue Service, Treasury Department, and Justice Department officials took the position that the wording of the Act would require publication or availability and indexing of all private letter rulings. During the 1963 Hearings on S. $1666,{ }^{78}$ a predecessor of the bill eventually

731967 ATT'Y GEN. MEMo., supra note 56, at 15.

74 See Davis, supra note 3 , at 775 .

75 Freedom of Information Act $\S 3(c), 5$ U.S.C. $\S 552(a)(3)$ (1970).

76 See text and notes at notes 57-65 supra.

77 S. REP. No. 813, 89th Cong., Ist Sess. 10 (1965).

78 See H.R. REP., No. 1497, 89th Cong., 2d Sess. (1966), at 11.

79 Hearings on S. 1666 \& S. 1663 Before the Subcomm. on Administrative Practice and 
enacted as the Freedom of Information Act, ${ }^{80} \mathrm{G}$. Andelot Belin, General Counsel of the Treasury Department, complained that the bill would require the publication and indexing of "decisions, rulings, and interpretations" that he believed did not need to be made public. Referring to letter rulings, he noted that under the availability section of the bill, "all of the interpretations of this type would have to be indexed and published or made publicly available ...."81 During the 1965 Hearings, ${ }^{82}$ Edwin F. Rains, Assistant General Counsel of the Treasury Department, told the Subcommittee that the Department already indexed IRS rulings having precedential significance (Revenue Rulings) and that he was opposed to the proposed Act's requirement of indexing "a vast amount of material of no precedential or permanent importance." 83 Later in those same hearings, Norbert A. Schlei, Assistant Attorney General, Office of Legal Counsel of the Justice Department, suggested that the proposed bill be "revised to include only those materials which an agency appropriately makes available 'for the guidance of the public;" "84 i.e., revised to conform with the more restrictive language of the 1946 Act. Despite such complaints and criticism, the language of the Act was not revised by either the subcommittee or Congress. Nevertheless, the Attorney General's 1967 Memorandum on the Freedom of Information Act looked at the Act's language and concluded, without explanation, that nonprecedential interpretations and rulings need not be made public, a conclusion inconsistent with the Justice Department's earlier interpretation.

No member of the subcommittee either repudiated or assented to the testimony of Messrs. Schlei, Rains, and Belin; thus it cannot be absolutely determined that they correctly assessed the Act's coverage. Nonetheless, their remarks, followed by the Senate's reiteration of the words of the statute in its Report, cast serious doubt on the interpretation adopted by the House.

3. Judicial Interpretation of the Act. Courts that have reviewed

Procedure of the Senate Comm. on the Judiciary, 88th Cong., Ist Sess. (1963) [hereinafter cited as 1963 Senate Hearings].

80 The wording of $\S 3(\mathrm{~b})$ of $S .1666$ was substantially the same as that of the $\S 3(\mathrm{~b})$ that was enacted: "every agency shall ... make available for public inspection and copying ... . interpretations adopted by the agency and affecting the public . ..." S. 1666, 88th Cong., Ist Sess. § 3(b) (1963).

811963 Senate Hearings, supra note 79, at 172, 177. See also the reference to the requirement of indexing formal taxpayer rulings. Id. at 280-81.

82 See Hearings on S. 1660, S. 1336, S. 1758 \& S. 1879 Before the Subcomm. on Administrative Practice and Procedure of the Senate Comm. on the Judiciary, 89th Cong., Ist Sess. (1965).

$83 \mathrm{Id}$. at 31 .

84 Id. at 204 (emphasis added). 
claims under the Freedom of Information Act have generally rejected the limitations in scope of application suggested in the House Report and the Attorney General's Memorandum. In Getman v. $N L R B,{ }^{85}$ for example, the United States Court of Appeals for the District of Columbia, noting that in some areas the House Report is "characteristically broader and goes beyond the express terms of the statute," concluded that "the Senate report is to be preferred over the House report as a reliable indication of the legislative intent." 86 In Soucie $v$. David ${ }^{87}$ the same court declared that the restrictions in the House report were in direct conflict with the Act, and noted that the legislative intent was "to assure public access to all government records whose disclosure would not significantly harm specific government interests." 88 The Sixth Circuit has recently concluded that because the House Report's comments support an "interpretation of the legislation which violates the language of the Act itself and conflicts with the Senate interpretation," the latter interpretation is to be preferred. ${ }^{89}$

A recent case, Tax Analysts $v . I R S,{ }^{90}$ has drawn together these interpretations of the Freedom of Information Act and, rejecting the House interpretation of the Act and the other Service arguments discussed above, ruled that the Freedom of Information Act requires disclosure of all rulings not proven to require confidentiality. ${ }^{91}$ This opinion is clearly in accord with the policy of the Act.

Thus, unless private letter rulings fall within one of the specific

85450 F.2d 670 (D.C. Cir. 1971).

86 Id. at 673 n.8; accord, Consumers Union v. VA, 301 F. Supp. 796, 801 (S.D.N.Y. 1969), appeal dismissed as moot, 436 F.2d 1363 (2d Cir. 1971), where the court was faced with the question whether the results of certain tests conducted by the Veteran's Administration had to be made available. The reports of the Senate and the House of Representatives regarding the coverage of the Freedom of Information Act were conflicting. The court noted that it was "confronted with a situation ... where the second House to act chose to express its intent in a committee report rather than in the statute whose language had already been defined by the other House." Id. at 800 . The court ordered the disclosure of the information on the grounds that the Senate report, favorable to disclosure, was before both houses of the Congress and that its interpretation "is more consistent with the purpose of the Act and it avoids a possible internal contradiction." Id. at 801. See also Benson v. GSA, 289 F. Supp. 590, 596-97, (W.D. Wash. 1968), aff'd on other grounds, 415 F.2d 878 (9th Cir. 1969).

87448 F.2d 1067, 1077, 1080 (D.C. Cir. 1971).

88 See also Sterling Drug, Inc v. FTC, 450 F.2d 698, 703 (D.C. Cir. 1971).

89 Hawkes v. IRS, 467 F.2d 787 (6th Cir. 1972).

90 Civil No. 841-72 (D.D.C. June 6, 1973), notice of appeal filed, D.C. Cir., Aug. 3, 1973. The service will undoubtedly maintain on appeal that the practical problems of availability are such as to require a bending of the statute to allow nondisclosure. The arguments used are likely to be those advanced in earlier debates over the desirability of disclosure of letter rulings.

91 Id. at 11 . 
exemptions to disclosure, they must be made public. Two of the exemptions could be applicable: one deals with matters specifically exempted from disclosure by statute, the other with "trade secrets and commercial or financial information obtained from any person and privileged or confidential." 22 These exemptions do not bar disclosure of letter rulings, however, since section $3(\mathrm{~b})$, the availability section, specifically provides for the deletion of identifying details "to the extent required to prevent a clearly unwarranted invasion of personal privacy ...." Thus, a letter ruling could be made available with confidential information deleted. A number of courts have noted this provision $^{23}$ and in fact the Service now deletes identifying details in publishing Revenue Rulings. ${ }^{94}$

There appear, therefore, to be sound reasons for the Service to disclose all private letter rulings. Such disclosure would increase public confidence in the letter ruling process and the tax system in general, would provide more equitable information distribution, and would improve input into the letter ruling process. Furthermore, such disclosure is probably required by the Freedom of Information Act. Representatives of the Service, however, maintain that disclosure would be harmful.

\section{iII. Objections to the Full Disclosure Proposal}

Opposition to public availability of private letter rulings is based primarily on three problems: the need to limit reliance strictly to the taxpayer receiving the ruling, thereby assuring the Service essential flexibility; the need for confidentiality, lest taxpayers hesitate to request rulings for fear of competitive injury; and the need to minimize administrative costs.

\section{A. Reliance by Nonrecipients}

As the private letter ruling program now operates, only the recipient may rely on the binding nature of the ruling sent to him. Another individual whose tax picture is indistinguishable from that of the recipient may not depend on the previous ruling as binding precedent. ${ }^{.5}$

92 A dispute has grown over the breadth of $\$ 3(e)(4)$. See Davis, supra note 3, at 787-92. For purposes of this discussion, the exemption may be given as broad or narrow a reading as desired without a change in result.

93 See Bristol-Myers Co. v. FTC, 424 F.2d 935, 938-39 (D.C. Cir. 1970); Grumman Aircraft Eng'r Corp. v. Renegotiation Bd., 425 F.2d 578, 580-81 (D.C. Cir. 1970).

94 26 C.F.R. $\S 601.702(\mathrm{~b})(2)$ (1972). For a more complete discussion of the possibility of deletion of details, see text and notes at notes 114-21 infra.

85 Rev. Proc. 72-8 \& 13.01, 1972 INT. Rev. Bull. No. 1. "[T]o hold that the Commissioner is bound by rulings specifically addressed to a taxpayer other than the one whose return is questioned would severely limit the usefulness of the ... practice of private administrative rulings." Goodstein v. Commissioner, 267 F.2d 127, 132 (lst Cir. 1959). See Book- 
Former Commissioner Caplin has noted that the major purpose of this policy has been to limit the possible damage from a mistake in the issuance of any one ruling. ${ }^{96}$ By limiting this risk, the Service can be more flexible in responding in the gray areas of the law, ${ }^{97}$ may use "lesser officials" to promulgate rulings, ${ }^{98}$ and may limit review of letter rulings. ${ }^{99}$

Many opponents of full disclosure of private letter rulings apparently presume that, under such a program, all taxpayers would be considered "recipients," enabling those whose "tax picture" fits within a ruling issued to another taxpayer to bind the Service. ${ }^{100}$ According to this

walter v. Brecklein, 357 F.2d 78 (8th Cir. 1966) where a taxpayer sought the same treatment given to other taxpayers in the same situation (the private rulings of the other taxpayers had been revoked prospectively; the complaining taxpayer had not requested or received his own ruling). The court held that "[t]axpayers without rulings are entitled only to be taxed the same as other taxpayers without rulings." Id. at 82; Weller v. Commissioner, 270 F.2d 294 (3d Cir. 1959). But see International Business Machs Corp. v. United States, 343 F.2d 914 (Ct. Cl. 1965), cert. denied, 382 U.S. 1028 (1966), where the court allowed IBM to rely on the ruling of a competitor. The case may be limited to "abuse of discretion" grounds. Popkin, supra note 52, at 498. See generally Calechman, Recent cases show need for caution in relying on IRS rulings and acquiescences, $23 \mathrm{~J}$. TAX. 122 (1965).

86 "Today, if an error is made in a given case, the revenue is not likely to be jeopardized to any great extent. On the other hand, if an erroneous interpretation in one case would be binding in all comparable cases, the Service quite naturally would be much more hesitant in exercising its discretionary authority to rule on close questions." Caplin, supra note 4 , at 27 .

97 See Rogovin, supra note 4, at 768.

98 Although the ultimate responsibility for determining Service policy lies with the Commissioner, rulings are technically issued under the authority of one of the Assistant Commissioners. See Rev. Proc. 72-73 \& 2.02, 1972 INr. REv. BuLL. No. 1. Most rulings, however, are actually promulgated by officials at the branch level. (See chart below). The Service maintains that higher levels of review would be necessary if a great number of taxpayers were permitted to bind the Service to a position in one letter ruling. See Caplin, supra note 4, at 27; Rogovin, supra note 4, at 767.

The following sample indicates a month's production of letter rulings signed and issued:

$\begin{array}{lccc}\text { Name of Branch } & \text { Branch } & \text { Division } & \text { Above Division } \\ \text { Corp. Income Tax } & 70 \% & 15 \% & 15 \% \\ \text { Indiv. Income Tax } & 74 \% & 24 \% & 2 \% \\ \text { Pension Trust } & 77 \% & 21 \% & 2 \% \\ \text { Reorganization } & 80 \% & 9 \% & 11 \% \\ \text { Excise Tax } & 85 \% & 10 \% & 5 \% \\ \text { Employment Tax } & 86 \% & 6 \% & 8 \% \\ \text { Estate and Gift } & 94 \% & 5 \% & 1 \% \\ \text { Exempt Orgs. } & 95 \% & 4 \% & 1 \% \\ \text { Reproduced in Caplin, supra note 4, at 28. } & & \end{array}$

99 Rogovin indicates that less than 2 percent of the letter rulings issued are reviewed above the divisional level prior to issuance, while more than 75 percent are issued with no review above the branch level. See Rogovin, supra note 4, at 766 n.49; Rose, supra note 7 , at 907 .

100 See Rogovin, supra note 4, at 767; Caplin, supra note 4, at $26 \mathrm{ff}$. 
view, an erroneous ruling could not be retroactively revoked as to any relying taxpayer's transaction. ${ }^{101}$ Permitting such broad reliance under the system of limited review now available could indeed reduce the Service's willingness to rule, especially in difficult cases. ${ }^{102}$ Further, giving binding effect to interpretations the Service wishes to undertake experimentally might perpetuate a weakness through the growth of an administrative practice built on those experimental rulings. Absent an error of law in the ruling, courts accepting this view would not allow the Service adequate flexibility to modify its policies. ${ }^{103}$ A program permitting every taxpayer to rely on others' rulings would thus require more thorough review within the Service, delaying the issuance of rulings. ${ }^{104}$ The advantages of an individualized, prompt response to a ruling request would be seriously compromised by permitting widespread reliance. ${ }^{105}$

According to former Commissioner Caplin, allowing reliance on another's letter rulings is also undesirable since two cases are seldom sufficiently alike to be granted the same treatment. ${ }^{108}$ Further, the Service would be faced with the administrative problem of determining who relies on letter rulings at what time. ${ }^{107}$ The Service presently has

101 See text at note 17 supra.

102 See note 96 supra. In constrast to the limited review given private letter rulings, published Revenue Rulings on which all taxpayers (whose "tax picture" falls within one) may rely, are given extensive review. According to Rose, all rulings proposed for publication must be approved by the Chief Counsel's Office. Rose, supra note 7, at 907; Rogovin, supra note 4, at 766 n.49. But see Popkin, supra note 52, at 495, noting that this review may be treated with a lack of urgency.

103 See Popkin, supra note 52, at 492-96. See also United States v. Correll, 389 U.S. 299, 305-06 (1967); Fribourg Navigation Co. v. Commissioner, 383 U.S. 272, 279 (1966).

104 "A policy of universal reliance would necessarily require higher levels of review. This, in turn, would greatly increase the time taken to issue rulings and might serve to cripple the present generally satisfactory rulings operation. It would also mean that rulings could rarely be expedited in the tight-deadline situations which today may merit extraordinary processing." Caplin, supra note 4, at 29.

105 Interviews by the author with members of the tax bar in New York and Chicago. Even though the speed with which letter rulings can be received is "acceptable" to many practitioners, it is clear that the Service's track record in this area is deteriorating. According to data derived from the Service, the following chart indicates the age of cases closed:

1963

1967

over 6 mos.
$20 \%$
$20 \%$
2-6 mos. $30 \%$ $49 \%$

under 2 mos.

$50 \%$

$31 \%$

Reproduced in L. Hart Wright, NeEded Change in INTERNal Revenue Service Conflict Resolution Procedures 49 (1970). See also Goldman, The Problem of Getting Rulings From the Reorganization Branch, 27 J. TAx. 341 (1967).

106 Caplin, supra note 4, at 27.

107 See id. at 29. See also Establishing Good Faith As A Defense in Certain Cases, in Hearings Before a Subcomm. of the Senate Comm. on the Judiciary on S.1752, 83d Cong., 2d Sess. (1954). Under the provisions of the bill, an individual would not be liable for 
no problem, however, in denying relief to a taxpayer who incorrectly claims to come within the factual setting of a Revenue Ruling; ${ }^{108}$ nor does the Service seem to encounter difficulty in verifying reliance on Revenue Rulings. ${ }^{108}$

Perhaps the best solution to the reliance problem is to be found in a disclosure program in which the separate functions of the Revenue Ruling and private letter ruling remain unchanged. Such a program could comply with the Freedom of Information Act yet limit the right of reliance to the named recipient. ${ }^{110}$ The Service would continue to select decisions of major importance for review and publication as Revenue Rulings, and taxpayers would continue to request private letter rulings when pretransaction advice binding in effect is needed..$^{111}$ The only major change would be the mandatory disclosure to the public of all private letter rulings issued. ${ }^{112}$

\section{B. The Need for Confidentiality}

Under the present system, taxpayers requesting private letter rulings can generally be assured that the Service's response will remain confidential. If all private letter rulings were made available to the public, it is argued, taxpayers might hesitate to request them. ${ }^{113}$ If competitors became aware of dealings before agreements were consummated, the success of some transactions might be jeopardized. Public knowledge of corporate plans at a sensitive pretransaction stage could also adversely affect the parties involved. Furthermore, the contemplated transaction might never occur and disclosure of the letter ruling request could prove embarrassing.

The need for confidentiality does not, however, require nondisclosure. Under the present system, important private letter rulings are eventually published as Revenue Rulings and confidentiality is maintained through extensive editing to remove as many identifying details

damages or penalties because of conduct not in conformity with any statute or other law if it is established that the conduct "was in conformity with and in good faith reliance on a rule, order, opinion, or other written statement of an agency responsible for administering that law ...."

108 See Kragen, The Private Ruling: An Anomaly of Our Internal Revenue System, 45 TAXEs 331, 338 (1967). A number of cases also show that factual situations are often similar. See, e.g., Bookwalter v. Brecklein, 357 F.2d 78 (8th Cir. 1966).

109 Caplin's argument may simply be that determining similarity of rulings and determining reliance are administratively unfeasible due to additional manpower requirements. As will be demonstrated below, this problem may be overcome within the system.

110 Assuming, of course, fulfillment by the recipient of the conditions cited in text at note 17 supra.

111 Rev. Proc. 72-9, 1972 INT. Rev. Bull. No. 1.

112 A similar plan has apparently been sketched out by former Chief Counsel Rogovin. See Reid, supra note 3, at 34.

113 Rogovin, supra note 4, at 767-68 n.60. 
as possible. ${ }^{114}$ It is possible to construct a program that will both permit disclosure and meet the requirements of confidentiality through the use of several safeguards.

The Revenue Procedures governing the issuance of letter rulings should be modified to indicate that tax counsel may include with his request for a ruling a proposed "public" form for that ruling-one that accurately reflects the nature of the transaction in question, yet maintains the confidentiality his client requires. ${ }^{115}$

When the Service issues the letter ruling care should be taken to respect a taxpayer's expressed preference for confidentiality, even where a proposed "public" form was not included with the ruling request. Both the Freedom of Information Act ${ }^{116}$ and the Regulations of the Service ${ }^{117}$ provide for deletion of identifying details when information is to be published or made available.

Within a stated period of time, perhaps thirty days from the issuance of the letter ruling, the ruling would become available in its "public" form. ${ }^{118}$ This period of delay would serve two functions: it would give the Service a sufficient period of time to prepare the letter for public disclosure and would provide the taxpayer with a "buffer" period of confidentiality in which to consummate the transaction without fear of disclosure of confidential information. If special problems arose that made publication inappropriate at the ordinary time, a proper showing of need would justify the Service granting an additional period of delay, perhaps until the completion of the transaction. ${ }^{119}$

If confidentiality cannot be maintained in a particular situation through the use of a "public" form of the letter ruling, the Freedom of Information Act probably does not require availability. ${ }^{120}$ Sound tax administration probably requires, however, that the Service not issue a

114 Rev. Proc. 72-1 § 6.01(2), 1972 INT. Rev. BuLr. No. 1. See also Rogovin, supra note 4, at 766. In fact, the Service is bound by statute to protect much of the information received from taxpayers. 18 U.S.C. $\S 1905$ (1970); 26 U.S.C. $\$ 7213$ (1970).

115 See Reid, supra note 3 , at 34 .

116 See § 3(b), 5 U.S.C. § 552(a)(2) (1970).

117 Rev. Proc. 72-1 § 6.01(2), 1972 INT. Rev. BuLl. No. 1 .

118 Transforming most letter rulings into "public" rulings should not require a large amount of time. Most could probably be "neutralized" simply through the deletion of names and addresses; others might require the additional deletion of certain confidential information.

110 A major company, for example, might make the necessary showing if it contemplated a transaction such that any ruling that accurately portrayed the transaction would inevitably endanger its consummation.

120 See $\$ \S 3(e)(4),(6), 5$ U.S.C. $\$ 552(b)(4)$, (6) (1970): “(4) trade secrets or financial information obtained from any person and privileged or confidential; ... (6) personnel and medical files and similar files the disclosure of which would constitute a clearly unwarranted invasion of personal privacy" need not be disclosed. Section 3(b), 5 U.S.C. § 552(a)(2) (1970) provides for deletion of identifying details to maintain confidentiality. 
private letter ruling if it will not be disclosed to the public. Granting selected rulings without disclosure would expose the Service to the lack of confidence that weakens the present system and particularly to charges of secret favoritism.

If a taxpayer believes that availability would be inconsistent with his best interests, he would be able to withdraw his ruling request and continue his transaction at his own risk. As noted previously, however, binding private letter rulings are highly coveted because of the tax certainty they provide. Large transactions generally present potentially serious tax consequences, and it is likely that only in the most sensitive of such cases would a prudent taxpayer forego this opportunity to gain certainty. ${ }^{121}$

\section{The Costs of Full Disclosure}

Advocates of secrecy maintain that given current manpower, the adoption of an extensive editing procedure for all private letter rulings would require a cutback in the number of rulings that could be issued, a slowdown in their issuance, or both. ${ }^{122}$ These developments, it is argued, would eliminate what many practitioners consider the greatest virtues of the present private letter rulings program: the ease with which rulings are granted, ${ }^{123}$ and the speed with which they are made available to the applicants. ${ }^{124}$ The envisioned problems, however, would

121 A further response to the argument that availability would reduce the demand for rulings is found in the fact that even under the present system, a taxpayer who requests a private letter ruling risks publication of his letter as a Revenue Ruling, thus exposing his transaction to the public.

122 See Dwan, supra note 4, at 146; Uretz, Freedom of Information and the IRS, 20 ARR. L. REv. 283, 288 (1967). It has also been suggested that the availability of 30,000 letter rulings would place a great burden on the tax practitioner who might be required to read through all of them. The new disclosure plan might also prove to have ramifications regarding the tax advisor's duty of care to his client. If failure to find a particular useful ruling out of the approximately 30,000 made available is to be construed as negligence, thus opening the attorney to a charge of malpractice, many attorneys are likely to prefer to work under the present system without disclosure. A number of options are available, however, to insure that the burdens of disclosure are not too great. The courts, as a matter of policy, may decide not to hold the attorney to a potentially burdensome standard of care. Rather, since the rulings are not binding for the researching attorney's client, the courts may determine that for purposes of the duty of care owed the client, the attorney need not look at these rulings at all. Another alternative is utilization of the various reporting services that would undoubtedly publish the most significant of the rulings. Attorneys could be held accountable for a knowledge of these rulings and be able to provide greater service to their clients by researching even further. A third alternative is suggested by members of the Tax Analysts and Advocates: private services may place the rulings on microfiche and index them by computer, greatly facilitating the attorney's research. If attorneys were to be held to a standard of care that required knowledge of all rulings, access to such a computerized system would lessen their burden.

123 Interviews by the author with members of the tax bar in New York and Chicago.

124 See note 105 supra. 
not necessarily be the result of a disclosure program. If a tax counsel's suggestion for a "public" form of his ruling were found acceptable in most instances, flexibility and speed could be maintained with only moderate increases in manpower. The issue, then, is whether the additional manpower required could in fact be provided without unreasonable expense.

The cost problem must be considered against the background of present financing of the rulings program. The Service does not presently charge a fee to recipients of private letter rulings, despite the substantial cost of researching, writing, and distributing the rulings. ${ }^{125}$ Taxpayers as a class pay for this service to recipients, even though only 30,000 to 40,000 rulings are issued each year. In view of the costs imposed by the ruling program and the potential additional costs of a disclosure program, it would be reasonable to allocate these costs so as to reflect more clearly the benefits derived from the services provided. The proposed system would confer benefits on three distinct groups. As under the present system, binding certainty would be available to the named recipient. Nonrecipient readers of the rulings would gain information on policy patterns, and taxpayers in general would gain the benefits of a more open system discussed earlier.

A fee system should be devised under which the recipients of these benefits are required to shoulder their proportionate share of the cost burden of the program. Charges for the benefits could be administered in several ways. The Service could make all letter rulings available at its reading rooms and charge a nominal fee for use. ${ }^{126}$ Additionally or alternatively, a small charge could be levied against the named recipient of the ruling. ${ }^{127}$

If these arrangements did not generate revenue sufficient to cover

125 It is plausible that the rulings program saves the Service more in litigation expense than it costs, see note 28 supra, but presumably the program also saves recipients these expenses. Moreover, the present method of financing letter rulings gives taxpayers no incentive to limit their use of the program to instances in which the information received is worth more than the cost of generating it.

126 This would be an equitable way to distribute the cost of disclosure if it is determined that significant benefits are conferred on the readers of the rulings. As a policy matter, however, the government may not wish to place any direct inhibitions on the ability of an individual to see what the Service has decided.

127 Fees could be set at a uniform level based on average cost. Alternatively, schedules of varying complexity could be provided that would reflect the administrative costs each increment of complexity would cause. If a reasonable scale of fees is provided, no taxpayer should be prevented from requesting a ruling merely because of the introduction of the fee. The only individuals who would be deterred by the fee from requesting a letter ruling are those taxpayers for whom the marginal benefit of obtaining a tailored, binding letter ruling rather than utilizing the information value of disclosed rulings of others is less than the marginal cost imposed by the fee. 
costs, the deficit could be made up from general revenues. Although not quantifiable, the value to the public of having tax decisions made in an atmosphere of openness, with the concomitant reductions in errors and favoritism, surely exceeds whatever deficit might occur. ${ }^{128}$

Statutory authority enabling the Service to charge appropriate fees for the provision of private letter rulings already exists under Title 31, section $438 \mathrm{a}$ of the United States Code. ${ }^{129}$ The broad language of that statute makes it clear that any valuable government benefit provided to an individual shall be self-sustaining "to the full extent possible." A private letter ruling is a service not only to the named recipient, but also to the readers of a ruling, each of whom receives a clarification of the Service's position on the tax consequences of a given transaction. The expense incurred by the Service in making all rulings public therefore could be transferred, under the authority of the statute, both to named recipients and to readers.

Guidelines for the charging of fees have been established by the Bureau of the Budget: "The provisions of this Circular cover all Federal activities which convey special benefits to recipients above and beyond those accruing to the public at large." 130 The examples provided show that private letter rulings readily fall within the Circular's guidelines. ${ }^{131}$

A number of other agencies already charge fees, usually for regis-

128 It may be argued that the most appropriate means to finance the ruling system is to completely socialize its cost by having the government (taxpayers) bear the total cost. One rationale for this argument is that the tax system is imposed, by compulsion, on all taxpayers and that tax rulings are, in fact, a practical necessity for a large class of taxpayers. Thus, because of a compulsory system imposed on all of American society (at least the taxpaying public), a group of taxpayers are forced to incur the cost and trouble of requesting a ruling. On this view, tax rulings are not really a "benefit" to taxpayers but are prerequisites necessitated by the system that benefits the public at large. Therefore, the argument runs, the cost of rulings should be borne not by individual recipients, but by taxpayers as a class.

129 The statute provides that any "work, service, publication, report, document, benefit, privilege, authority, use franchise, license, permit, certificate, registration, or similar thing of value or utility performed, furnished, provided, granted, prepared, or issued by any Federal agency ... to or for any person ... shall be self-sustaining to the full extent possible, and the head of each Federal agency is authorized by regulation . . . to prescribe therefore such fee, charge, or price . . . to be fair and equitable taking into consideration direct and indirect costs to the government, value to the recipient, public policy or interest served ...."

The statute has withstood three challenges thus far: Pankey Land \& Cattle Co. v. Hardin, 427 F.2d 43 (10th Cir. 1970) (grazing fee); Reinoehl v. Hershey, 426 F.2d 815 (9th Cir. 1970) (fees for copying of draft board records); Aeronautical Radio, Inc. v. United States, 335 F.2d 304 (7th Cir. 1964), cert. denied, 379 U.S. 966 (1965) (FCC fee schedule). 130 Bureau of the Budget Circular No. A-25, at 1 (Sept. 23, 1959).

131 Id. at 1-2. 
trations or the granting of licenses. ${ }^{132}$ For example, the CAB established a fee schedule for licensing, ${ }^{133}$ noting that "to insist that applicants pay part of the costs incurred in granting them licenses to carry on a profitable business . . . is fair and equitable." 134 The SEG also requires the payment of a fee at the time of filing a registration. ${ }^{135}$

The Freedom of Information Act provides for fees for requests to provide identifiable records. ${ }^{136}$ The Attorney General has noted in this regard that pursuant to Title 31, section 438a of the United States Code, "an appropriate fee should be required for searching [records] as distinguished from a fee for copying. Such fees should include indirect costs, such as the cost to the agency for the services of the government's employee who searches for, reproduces, certifies, or authenticates in some manner copies of the requested documents." 137

\section{CONGLUSION}

The Service should make all private letter rulings available for public inspection. Availability is advantageous to the Service, to named ruling recipients, to readers of the rulings, and to the general public. This policy mandate is supported by the requirements of the Freedom of Information Act. If the program leads to additional administrative costs, these costs could properly be passed on, under existing legislation, to the beneficiaries of the disclosure program.

Stuart I. Oran

132 See Staff of Subcomm. on Administrative Practice and Procedure of the Senate Comm. on the Judictary, 90th Cong., 2D Sess. The freedom of Information Act (Ten Months Review) 51 (Comm. Print 1968) [hereinafter cited as Ten Months Review].

133 C.A.B. REg. No. OR-27. For an example of a schedule, see 14 C.F.R. § 389.25.

134 TEN MONTHS REVIEW, supra note 132 , at 52 .

13515 U.S.C. $\$ 77(f)$ (b) (1970). The fee is equal to $1 / 50$ of 1 percent of the maximum aggregate price at which such securities are to be offered, with a minimum of $\$ 100$. For a discussion of the reasons for the fee, see S. REP. No. 812, 89th Cong., 1st Sess. (1965). 136 § $3(c), 5$ U.S.C. § 552(a)(3) (1970).

1371967 ATr'y Gen. MEMo., supra note 56, at 26. In Benson v. GSA, 289 F. Supp. 590, 596-97 (W.D. Wash. 1968), the court suggested that this type of charge be levied against the recipient to cover the cost of deleting information. 